\title{
SEISMIC EVALUATION OF MUTISTOREY BUILDING WITH SOFT STOREY
}

\author{
Md Rihan Maze ${ }^{1}$, S S Dyavanal ${ }^{2}$ \\ ${ }^{1}$ PG Student, Civil Engg Dept BVBCET Hubli, Karnataka, India,rihanmaaz@gmail.com \\ ${ }^{2}$ Professor' Civil Engg Dept BVBCET Hubli, Karnataka, India,ssdyavanal@bvb.edu
}

\begin{abstract}
Most of the reinforced concrete $(R C)$ structures are not designed to resist major or moderate earthquakes. The designs of such building are regularly done by using gravity loading without considering the earthquake load. Thus these buildings are vulnerable during the event of an earthquake.. In present study bare frame and soft storey are modeled considering special and ordinary moment resisting frame (SMRF \& OMRF) for medium soil profile under zone III. The masonry infill panels were modeled as equivalent diagonal strut seven and ten storey buildings are considered to represent medium and high rise buildings, equivalent static and response spectrum analysis was performed on bare frame, infill frames as brick and infill frame as solid concrete block using SAP 2000 V15 software. Nonlinear static pushover analysis carried out for default-hinge properties, $M, P M, V$ and $P$ hinges are applied to beam, column and strut available in some programs based on the FEMA-356 and ATC-40 guidelines. While such documents provide the hinge properties for several ranges of detailing, programs may implement averaged values. The performance of building frames were compared with bare frame, in terms of ductility, safety, and stiffness. The investigation concludes that the performance of the buildings having non-ductile moment resisting frames can be improved by adding infill walls and SMRF building models are found more resistant to earthquake loads as compared to the OMRF building models in terms of performance level, performance point and hinging variation the performance of building for OMRF lies in LS to CP range where as SMRF are found under life safety range, this shows in high seismicity region the ductile detailing must be adopted to avoid the vulnerability of building for tremor loads.
\end{abstract}

Key Words: Soft Storey, OMRF, SMRF, Pushover Analysis, Ductility, Stiffness, Performance Levels $* * *$

\section{INTRODUCTION}

With the high cost of land in most urban areas of India, the developers of residential and commercial buildings are eager to accommodate the vehicular parking requirements within the front foot of the building that is at the ground floor, while the upper stories of the RC concrete frames are infilled with brick masonry walls. From experience of the recent severe Bhuj earthquake 2001, the multistoreyed buildings with open ground floors collapsed due to lesser strength and stiffness of ground storey compared to upper stories, which are stiffened by masonry infill walls. The buildings are also designed only for gravity load combination with RC detailing not conforming to IS: 13920-1993 i.e., non- ductile moment resisting frame buildings, which were unable to resist the lateral earthquake forces.

\section{ANALYTICAL MODELING}

The plan layout of the reinforced concrete moment resisting frame buildings of four, seven and ten storeyed buildings is shown in Fig. 1 (i) The building is modeled as bare frame (ii) open first storey and unreinforced brick infill in the upper storeys, (iii)open first storey and unreinforced solid concrete block infill in the upper storeys. The elevations of the different building models considered are shown in Fig1 the bottom storey height is $4.8 \mathrm{~m}$ and a height of $3.6 \mathrm{~m}$ is kept for all the other storeys in both the buildings. The building is analyzed for the $2 \mathrm{D}$ frame the building is considered to be located in seismic zone III Hubli-Dharwad region and intended for use as an office. In the seismic weight calculations, only $25 \%$ of the live load is considered. Masonry brick and solid concrete block walls are modeled by considering equivalent diagonal strut. The material properties and thickness of struts are same as that of masonry wall; the effective width of strut is calculated as proposed by Smith and Hendry, M (moment hinge), PM (axial force and Moment hinge), V (Shea $\mathrm{r}$ hinge) and $\mathrm{P}$ (axial force hinge) hinges with hinge properties as per FEMA 356 are assigned at both ends of beam, column a nd strut elements respectively. In the present investigation the building models are analyzed by taking the most severe load combination as pe r IS:1893(Part1)-2002 Equivalent static and nonlinear static pushover analysis carried out and the effect of OMRF and SMRF considering infill walls are studied and compared with the bare frame 

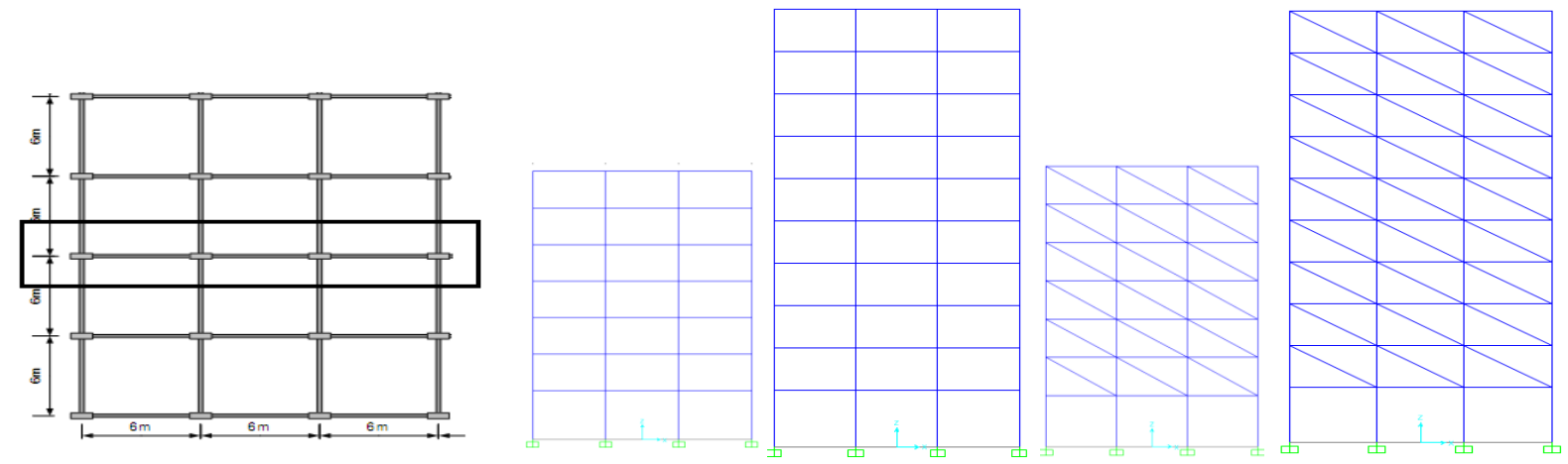

Fig 1 Plan and Elevation of seven and ten storey bare frame and infill frame buildings

\section{RESULTS AND DISCUSSION}

\subsection{Natural Periods}

The codal IS: 1893(Part1)-2002 and analytical (SAP 2000) natural periods of the building models are presented in the Table 1.

Table 1 Codal and analytical natural periods

\begin{tabular}{|c|c|c|c|c|c|c|}
\hline \multicolumn{3}{|c|}{ Bare frame } & \multicolumn{2}{c|}{$\begin{array}{c}\text { Infill wall as } \\
\text { brick }\end{array}$} & \multicolumn{2}{c|}{$\begin{array}{c}\text { Infill wall as solid } \\
\text { concrete block }\end{array}$} \\
\hline $\begin{array}{c}\text { Mo } \\
\text { del }\end{array}$ & Codal & $\begin{array}{c}\text { Analyti } \\
\text { cal }\end{array}$ & Codal & $\begin{array}{c}\text { Analy } \\
\text { tical }\end{array}$ & Codal & $\begin{array}{c}\text { Analytic } \\
\text { al }\end{array}$ \\
\hline 4 & 0.59 & 1.01 & 0.33 & 0.69 & 0.33 & 0.64 \\
\hline 7 & 0.87 & 1.60 & 0.53 & 0.77 & 0.56 & 0.78 \\
\hline 10 & 1.13 & 1.61 & 0.79 & 0.84 & 0.79 & 0.84 \\
\hline
\end{tabular}

Due to the presence of infill stiffness the natural period gets reduced as compared to bare frame natural period. The natural period directly affects the spectral accerlation $\mathrm{S}_{\mathrm{a}} / \mathrm{g}$, it can be observed in Fig.2 of IS:1893(Part1)-2002, where the spectral accerlation coefficient increases as the time period reduces. The codal time period and analytical time period do not tally each other because codal calculation is depends on empirical formula. It is noticed that the modeling of infill with equivalent diagonal struts significantly effects the fundamental natural period, which is a function of mass, stiffness and damping characteristics of the building.

\subsection{Story Shear}

In the response spectrum method the design of base shear $(\mathrm{Vb})$ is made equal to the $\overline{\mathrm{Vb}}$ base shear obtained from equivalent static method as per IS: 1893(Part1)-2002 by applying the scaling factor calculated as shown in Tables 2-4

Table 2 Base Shear and scaling factor for bare frame building models

\begin{tabular}{|c|c|c|c|c|c|c|}
\hline \multirow{2}{*}{$\begin{array}{c}\text { Stor } \\
\text { ey }\end{array}$} & \multicolumn{3}{|c|}{ OMRF } & \multicolumn{3}{|c|}{ SMRF } \\
\cline { 2 - 7 } & $\overline{\mathrm{Vb}}$ & $\mathrm{Vb}$ & $\begin{array}{c}\text { Scaling } \\
\text { factor }\end{array}$ & $\overline{\mathrm{Vb}}$ & $\mathrm{Vb}$ & $\begin{array}{c}\text { Scaling } \\
\text { factor }\end{array}$ \\
\hline 7 & $\begin{array}{c}180 . \\
61\end{array}$ & $\begin{array}{c}56.4 \\
2\end{array}$ & 3.21 & $\begin{array}{c}112 . \\
37\end{array}$ & $\begin{array}{c}55.5 \\
5\end{array}$ & 2.02 \\
\hline & 207. & 58.8 & & $\begin{array}{c}127 . \\
70\end{array}$ & $\begin{array}{c}78.0 \\
8\end{array}$ & 1.62 \\
\hline
\end{tabular}

Table 3 Base Shear and scaling factor for infill wall as brick frame building models

\begin{tabular}{|c|c|c|c|c|c|c|}
\hline \multirow{2}{*}{$\begin{array}{c}\text { Stor } \\
\text { ey }\end{array}$} & \multicolumn{3}{|c|}{ OMRF } & \multicolumn{3}{|c|}{ SMRF } \\
\cline { 2 - 7 } & $\overline{\mathrm{Vb}}$ & $\mathrm{Vb}$ & $\begin{array}{c}\text { Scaling } \\
\text { factor }\end{array}$ & $\overline{\mathrm{Vb}}$ & $\mathrm{Vb}$ & $\begin{array}{c}\text { Scaling } \\
\text { factor }\end{array}$ \\
\hline 7 & 340. & 151. & & 201. & 151. & \\
& 1 & 41 & 2.24 & 94 & 42 & 1.333 \\
\hline 10 & 352. & 191. & & 216. & 203. & \\
24 & 22 & 1.84 & 23 & 26 & 1.069 \\
\hline
\end{tabular}

Table 4 Base Shear and scaling factor for infill wall as solid concrete block frame building models

\begin{tabular}{|c|c|c|c|c|c|c|}
\hline \multirow{2}{*}{$\begin{array}{c}\text { Stor } \\
\text { ey }\end{array}$} & \multicolumn{4}{|c|}{ OMRF } & \multicolumn{3}{c|}{ SMRF } \\
\cline { 2 - 7 } & $\overline{\mathrm{Vb}}$ & $\mathrm{Vb}$ & $\begin{array}{c}\text { Scaling } \\
\text { factor }\end{array}$ & $\overline{\mathrm{Vb}}$ & $\mathrm{Vb}$ & $\begin{array}{c}\text { Scaling } \\
\text { factor }\end{array}$ \\
\hline 7 & $\begin{array}{c}346 . \\
55\end{array}$ & $\begin{array}{c}152 . \\
89\end{array}$ & 2.26 & $\begin{array}{c}205 . \\
04\end{array}$ & 152.63 & 1.343 \\
\hline 10 & $\begin{array}{c}358 . \\
96\end{array}$ & $\begin{array}{c}193 . \\
71\end{array}$ & 1.9 & $\begin{array}{c}217 . \\
76\end{array}$ & 204.42 & 1.065 \\
\hline
\end{tabular}

Underestimation of design base shear is observed in case of bare models for 4 storey infill as brick and solid concrete block building it is found $22.11 \%, 23.23 \%$ more than the bare frame building for 7 storey infill as brick and solid concrete block building it is found $44.35 \%, 45.19 \%$ more than the bare frame building and for 10 storey infill as brick and solid concrete block building it is found $41.17 \%, 41.58 \%$ more than the bare frame building for response spectrum and equivalent static method.

Hence it can be conclude that ,the design of base shear increases with increases in mass and stiffness of masonry infill wall and vice versa.

\subsection{Lateral Deformations}

Lateral displacement profiles for seven and ten storey buildings models obtained by equivalent static (ESM) by considering OMRF and SMRF are shown in Figs. 2-3 and Tables 5-6 gives the values of lateral displacement along longitudinal direction 
Table 5 Lateral displacements for seven storey building in $\mathrm{mm}$

\begin{tabular}{|c|c|c|c|c|c|c|}
\hline \multirow{2}{*}{ Storey } & \multicolumn{3}{|c|}{ OMRF } & \multicolumn{2}{c|}{ SMRF } \\
\cline { 2 - 4 } & \multirow{2}{*}{ Bare frame } & \multicolumn{2}{|c|}{ Infill wall } & \multirow{2}{*}{ Bare frame } & \multicolumn{2}{c|}{ Infill wall } \\
\cline { 3 - 4 } & & Brick & Concrete block & & Brick & Concrete block \\
\hline 7 & 40.69 & 11.3 & 11.4 & 25.45 & 6.7 & 6.77 \\
\hline 6 & 38.4 & 10.88 & 11.01 & 24 & 6.4 & 6.52 \\
\hline 5 & 34.59 & 10.39 & 10.51 & 21.4 & 6.1 & 6.23 \\
\hline 4 & 29.29 & 9.85 & 9.97 & 17.7 & 5.8 & 5.91 \\
\hline 3 & 22.34 & 9.28 & 9.41 & 13.7 & 5.5 & 5.57 \\
\hline 2 & 15.31 & 8.76 & 8.89 & 9.2 & 5.2 & 5.27 \\
\hline 1 & 7.52 & 7.11 & 7.25 & 5.2 & 4.8 & 4.89 \\
\hline
\end{tabular}

Table 6 Lateral displacements for ten storey building in $\mathrm{mm}$

\begin{tabular}{|c|c|c|c|c|c|c|}
\hline \multirow{3}{*}{ Storey } & \multicolumn{3}{|c|}{ OMRF } & \multicolumn{2}{c|}{ SMRF } \\
\cline { 2 - 4 } & \multirow{2}{*}{ Bare frame } & \multicolumn{2}{|c|}{ Infill wall } & \multirow{2}{*}{ Bare frame } & \multicolumn{2}{c|}{ Infill wall } \\
\cline { 3 - 4 } \cline { 6 - 7 } & & Brick & Concrete block & & Brick & Concrete block \\
\hline 10 & 64.25 & 11.92 & 11.99 & 32.02 & 6.81 & 6.75 \\
\hline 9 & 62.08 & 11.3 & 11.36 & 30.91 & 6.44 & 6.39 \\
\hline 8 & 58.36 & 10.62 & 10.68 & 29.02 & 6.04 & 6 \\
\hline 7 & 53.07 & 9.9 & 9.96 & 26.4 & 5.63 & 5.58 \\
\hline 6 & 46.37 & 9.15 & 9.21 & 23.67 & 5.2 & 5.16 \\
\hline 5 & 38.45 & 8.4 & 8.45 & 20.51 & 4.78 & 4.74 \\
\hline 4 & 30.93 & 7.67 & 7.73 & 16.98 & 4.36 & 4.32 \\
\hline 3 & 22.92 & 6.96 & 7.02 & 13.16 & 3.98 & 3.93 \\
\hline 2 & 14.66 & 6.34 & 6.41 & 9.13 & 3.64 & 3.59 \\
\hline 1 & 6.71 & 5.61 & 5.69 & 4.94 & 3.27 & 3.22 \\
\hline
\end{tabular}

The lateral displacement of a building is a function of the stiffness, the lateral displacement of the building decreases with the increase in the lateral stiffness; hence the displacement of the soft storey is less than the bare frame. Comparing the roof displacement obtained from equivalent static method with considering OMRF, a decrease by $65-81.45$ $\%$ were observed compare to bare frame building models and for SMRF decrease by $63.75-73.67 \%$, were observed compare to bare frame building models From the results it is observed that the stiffness is increased in infill wall models. This implies that the infill panel increases the lateral stiffness of the building studied, measured in terms of the roof displacement there by reducing displacements in all storey levels compared to bare frame models
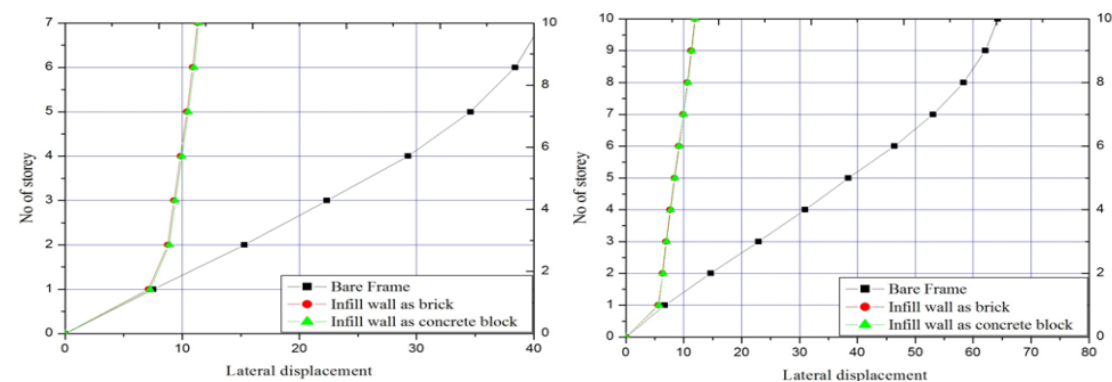

Fig 2 Lateral displacement for seven and ten storey building with OMRF
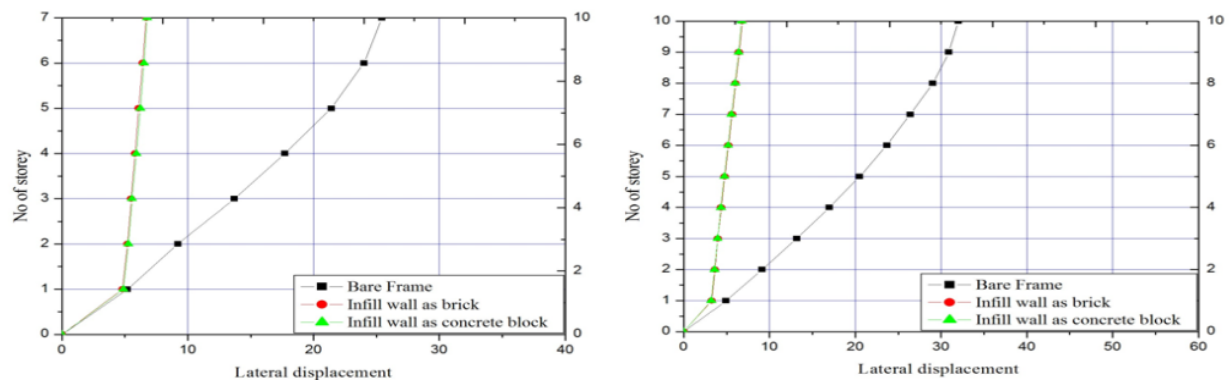

Fig 3 Storey drift for seven and ten storey building with SMRF 


\subsection{Performance Point and Location of Hinges}

The base force, displacement and the location of the hinges at the performance point, for various performance levels along longitudinal direction for all buildin g models are presented in the Tables 7-12 the locations of the hinges formed at the performance point, target displacement and base force at ultimate state are shown in the Table 7-12. In most of the buildings, flexural plastic hinges are formed in the first storey because of open ground storey. Initially formations of hinge are observed in beam ends at lower storeys, then propagate to upper stories, and continue with yielding of base columns the plastic hinges are formed in the beams and OMRF and SMRF. Shear design is major important factor in concrete structure since strength of concrete in tension is lower than its strength in compressions. However, past earthquakes reveal that majority of the reinforced concrete (RC) structures failed due to shear.

Failure of shear hinges about 5-8\% for OMRF and 1-5 \% for the SMRF building models are observed at the ultimate point in the bottom storey column, which shows lack of confining reinforcement in OMRF building models

Table 7 Performance point and location of hinges for bare frame considering OMRF

\begin{tabular}{|c|c|c|c|c|c|c|c|c|}
\hline MODEL & $\begin{array}{c}\text { Base Force } \\
\mathrm{kN}\end{array}$ & Displacement mm & AtoB & BtoIO & IOtoLS & LStoCP & CPtoE & Total \\
\hline 7 & 715.63 & 165.96 & 165 & 26 & 5 & 0 & 0 & 196 \\
\hline Ultimate & 825.29 & 386.3 & 142 & 14 & 13 & 2 & 15 & 196 \\
\hline 10 & 810.39 & 141.3 & 237 & 31 & 12 & 0 & 0 & 280 \\
\hline Ultimate & 1008.33 & 434.11 & 192 & 29 & 22 & 6 & 31 & 280 \\
\hline
\end{tabular}

Table 8Performance point and location of hinges considering brick infill masonry with OMRF

\begin{tabular}{|c|c|c|c|c|c|c|c|c|}
\hline MODEL & Base Force $\mathrm{kN}$ & $\begin{array}{c}\text { Displacement } \\
\mathrm{mm}\end{array}$ & AtoB & BtoIO & IOtoLS & LStoCP & CPtoE & Total \\
\hline 7 & 902.58 & 69.94 & 215 & 5 & 2 & 0 & 8 & 230 \\
\hline Ultimate & 1054.04 & 184.9 & 208 & 3 & 2 & 9 & 8 & 230 \\
\hline 10 & 1040.69 & 84.58 & 306 & 12 & 8 & 0 & 8 & 334 \\
\hline Ultimate & 1478.6 & 381.3 & 306 & 10 & 10 & 0 & 8 & 334 \\
\hline
\end{tabular}

Table 9 Performance point and location of hinges considering solid concrete block as infill masonry with OMRF

\begin{tabular}{|c|c|c|c|c|c|c|c|c|}
\hline MODEL & Base Force $\mathrm{kN}$ & Displacement $\mathrm{mm}$ & AtoB & BtoIO & IOtoLS & LStoCP & Cpto E & Total \\
\hline 7 & 907.17 & 72.1 & 215 & 5 & 4 & 2 & 6 & 232 \\
\hline Ultimate & 915.5 & 162.1 & 202 & 8 & 2 & 2 & 8 & 222 \\
\hline 10 & 1038.35 & 76.1 & 306 & 12 & 8 & 0 & 8 & 334 \\
\hline Ultimate & 1066.18 & 189.53 & 304 & 12 & 8 & 0 & 10 & 334 \\
\hline
\end{tabular}

Table 10 Performance point and location of hinges for bare frame considering SMRF

\begin{tabular}{|c|c|c|c|c|c|c|c|c|}
\hline MODEL & $\begin{array}{c}\text { Base Force } \\
\mathrm{kN}\end{array}$ & $\begin{array}{c}\text { Displacement } \\
\mathrm{mm}\end{array}$ & AtoB & BtoIO & IOtoLS & LStoCP & CPtoE & Total \\
\hline 7 & 498.16 & 176.52 & 162 & 21 & 13 & 0 & 0 & 196 \\
\hline Ultimate & 540.82 & 570.5 & 151 & 9 & 5 & 8 & 15 & 196 \\
\hline 10 & 670.93 & 169.58 & 242 & 32 & 6 & 0 & 0 & 280 \\
\hline Ultimate & 736.07 & 475.79 & 222 & 23 & 9 & 7 & 19 & 280 \\
\hline
\end{tabular}

Table 11Performance point and location of hinges considering brick infill masonry with SMRF

\begin{tabular}{|c|c|c|c|c|c|c|c|c|}
\hline MODEL & $\begin{array}{c}\text { Base Force } \\
\mathrm{kN}\end{array}$ & Displacement mm & AtoB & BtoIO & IOtoLS & LStoCP & CPtoE & Total \\
\hline 7 & 908.06 & 71.23 & 221 & 3 & 0 & 4 & 4 & 232 \\
\hline Ultimate & 915.31 & 107.56 & 221 & 3 & 0 & 0 & 8 & 232 \\
\hline 10 & 1184.02 & 80.12 & 313 & 10 & 7 & 0 & 4 & 334 \\
\hline Ultimate & 1184.1 & 113.8 & 312 & 8 & 4 & 2 & 8 \\
\hline
\end{tabular}


Table 12 Performance point and location of hinges considering solid concrete block as infill masonry with SMRF

\begin{tabular}{|c|c|c|c|c|c|c|c|c|}
\hline MODEL & $\begin{array}{c}\text { Base Force } \\
\mathrm{kN}\end{array}$ & Displacement $\mathrm{mm}$ & AtoB & BtoIO & IOtoLS & LStoCP & Cpto E & Total \\
\hline 7 & 907.6 & 71.23 & 221 & 3 & 0 & 4 & 4 & 232 \\
\hline Ultimate & 915.51 & 125.6 & 221 & 3 & 0 & 0 & 8 & 232 \\
\hline 10 & 1183.332 & 80.52 & 314 & 9 & 7 & 0 & 4 & 334 \\
\hline Ultimate & 1189.396 & 131.2 & 312 & 8 & 6 & 0 & 8 & 334 \\
\hline
\end{tabular}

Failure of shear hinges about $5-8 \%$ for OMRF and $1-5 \%$ for the SMRF building models are observed at the ultimate point in the bottom storey column, which shows lack of confining reinforcement in OMRF building models

Flexural hinges are found under life safety range for the both OMRF and SMRF building models at the performance points and at the ultimate state $3-12 \%$ of hinges are found CP to E for all OMRF building models and for SMRF building models it is 2-8\%.however the performance of the buildings having non-ductile moment resisting frames can be improved by adding infill walls.

\subsection{Ductility Ratio (DR)}

The ability of the structure or its component, or the material used to offer resistance in the inelastic domain of response is described by the term ductility. The ductility of a structure is in fact one of the most important factors affecting its earthquake performance

\subsection{Safety Ratio (SR)}

The ratio of base shear force at performance point to the base shear by equivalent static method which is called safety ratio [9].

\subsection{Global Stiffness (GS)}

The ratio of performance base shear to performance displacement is called as global stiffness [9]

Table 13 DR, SR and GS for bare frame building models

\begin{tabular}{|c|c|c|c|c|c|c|}
\hline \multirow{2}{*}{ Model } & \multicolumn{3}{|c|}{ OMRF } & \multicolumn{3}{|c|}{ SMRF } \\
\cline { 2 - 7 } & DR & SR & GS & DR & SR & GS \\
\hline 7 Storey & 1.65 & 3.96 & 4.31 & 2.56 & 4.43 & 2.82 \\
\hline 10 Storey & 1.51 & 3.9 & 5.74 & 1.96 & 5.24 & 3.95 \\
\hline
\end{tabular}

Table 14 DR, SR and GS for brick infill wall frame

\begin{tabular}{|c|c|c|c|c|c|c|}
\hline \multirow{2}{*}{ Models } & \multicolumn{3}{|c|}{ OMRF } & \multicolumn{3}{c|}{ SMRF } \\
\cline { 2 - 7 } & DR & SR & GS & DR & SR & GS \\
\hline 7 Storey & 2.88 & 2.65 & 12.91 & 2.91 & 4.5 & 12.75 \\
\hline 10 Storey & 3.32 & 2.95 & 12.3 & 3.15 & 5.48 & 14.78 \\
\hline
\end{tabular}

Table 15 DR, SR and GS for solid concrete block infill wall frame building models

\begin{tabular}{|c|c|c|c|c|c|c|}
\hline \multirow{2}{*}{ Models } & \multicolumn{3}{|c|}{ OMRF } & \multicolumn{3}{c|}{ SMRF } \\
\cline { 2 - 7 } & DR & SR & GS & DR & SR & GS \\
\hline 7 Storey & 2.95 & 2.62 & 12.58 & 2.93 & 4.43 & 12.74 \\
\hline 10 Storey & 3.41 & 2.89 & 13.64 & 3.19 & 5.43 & 14.7 \\
\hline
\end{tabular}

The lateral stiffness of the building increases the lateral strength, but reduces the energy absorption capacity of the building, hence ductility ratio decreases. From above result it is clear that the ductility ratio increases with increase in the column stiffness and decreases with increase in the wall stiffness and also P-delta play an important role in the ductile behavior of the buildings. In 7 storey bare framed building, infill as brick and solid concrete block masonry the DR are found within the targeted ductility ratio $(\mathrm{R}=3)$ In 10 storey framed building with bare frame the DR are found within the targeted ductility ratio $(\mathrm{R}=3)$ the frame with infill as brick and solid concrete block masonry are found more than the targeted ductility ratio. From the above results it can be observed that for four, seven and ten storey frame building models with infill frame are found 1-3 times safer compare to the bare frame models and the SMRF buildings models are found more safer than the OMRF building models. The above results reveals that for four, seven and ten storey frame building models with infill frame as solid concrete block is found more global stiffness than the infill as brick masonry and bare frame . In four, seven and ten storey frame building models with infill frame as brick and solid concrete block the GS is increased by, $61.93 \%, 61.91 \%$ for seven storey and 53\%, 57.6 $\%$ for ten storey compare to the bare frame building models

\section{CONCLUSIONS}

Based on the results obtained from different analysis for the various building models, the following conclusion is drawn.

1. The codal time period and analytical time period do not tally each other because codal calculation is depends on empirical formula

2. Underestimation of design base shear in case of bare models as compared to the infill models the design of base shear increases with increases in mass and stiffness of masonry infill wall and vice versa.

3. Infill panel increases the lateral stiffness of the building, measured in terms of the roof displacement there by reducing displacements in all storey levels compared to bare frame models. 
4. Failure of shear hinges about 5-8\% for OMRF and 1$5 \%$ for the SMRF building models are observed at the ultimate point in the bottom storey column, which shows lack of confining reinforcement in OMRF building models

5. Flexural hinges are found under life safety range for the both OMRF and SMRF building models at the performance points and at the ultimate state 3-12\% of hinges are found $\mathrm{CP}$ to $\mathrm{E}$ for all OMRF building models and for SMRF building models it is $2-8 \%$.

6. SMRF building models are found more resistant to earthquake loads as compared to the OMRF building models in terms of performance level at performance point and hinging variation the performance of building for OMRF lies in LS to CP range where as SMRF are found under life safety range at ultimate state ,this shows in high seismicity region the ductile detailing must be adopted

7. Ductility if found more in the infill frame wall compare to the bare frame building models in both non and ductile moment resisting frame buildings

8. Safety ratio and global stiffness is found more for the infill building models compared to the bare frame building models and the SMRF buildings models are more found safer than the OMRF building models.

\section{REFERENCES}

1. Agarwal P and Shrikhande M (2006), "Earthquake design of structures" Prentice Hall of India Private Limited New Delhi India.

2. Applied Technology Council (1996), "Seismic evaluation and retrofit of concrete buildings", Vol.1\& 2, California.

3. Federal Emergency Management Agency, FEMA356 (2000), "Pre standard and commentary for seismic rehabilitation of buildings". Washington (DC),

4. Hemant B. Kaushik, Durgesh C. Rai and Sudhir K. Jain (2007) "Stress-Strain Characteristics of Clay Brick Masonry under Uniaxial Compression" Journal of Materials in Civil Engineering ASCE September 2007.

5. IS:1893(Part1)-2002, Criteria for earthquake resistant design of structure, General Provision and Building.

6. Veeresh B Karkatti, Dyavanal S S and Annigeri S A (2006) "Seismic Evaluation and Retrofitting of Soft Ground RC Multistorey Buildings" Journal of Structural Engineering 